\title{
A thymus szerkezete a huszonegyedik század elején
}

\author{
Bódi Ildikó dr. ${ }^{1}$ - H.-Minkó Krisztina dr. ${ }^{1}$ - Prodán Zsolt dr. ${ }^{2}$ \\ Nagy Nándor dr. ${ }^{1}$ - Oláh Imre dr. ${ }^{1}$
}

\author{
${ }^{1}$ Semmelweis Egyetem, Általános Orvostudományi Kar, Anatómiai, Szövet- és Fejlődéstani Inézet, Budapest \\ ${ }^{2}$ Gottsegen György Országos Kardiológiai Intézet, Budapest
}

\begin{abstract}
A thymus klasszikus hisztológiai tulajdonságai: a kéreg- és velőállomány, a Hassall-testek és a mirigyekre jellemző lebenyezettség. Az anti-páncitokeratin festése azt mutatja, hogy a kérgi és velőhámsejtek keratinmintázata különböző. A velőállomány további kompartmentekre különül: keratinpozitív hálózatra és keratinnegatív területre. A keratinpozitív hálózat összeköttetésben áll a kérgi hámreticulummal, míg a keratinnegatív terület folyamatos a septumok kötôszöveti állományával. A keratinnegatív területnek, a toknak és a septumnak a támasztószövete reticularis kötőszövet. A kéregállományt a tok és a septumok reticularis kötőszövetétől folyamatos bazális membrán választja el, de a keratinnegatív területek és a keratinpozitív hálózat határánál a bazális membrán szakadozottá válik. Ez az immunhisztokémiai lelet az első, amely magyarázhatja, hogy miért nincs a velőállományában vér-thymus barrier. A keratinnegatív terület és a septumok támasztószövetének azonossága azt sugallja, hogy a sövények és a keratinnegatív területek azonos eredetúek. A thymus tokja és sövényei a cranialis ganglionlécből származnak, ezért feltételezzük, hogy a keratinnegatív terület is ganglionléc-eredetű. A velóállomány vérerei a keratinnegatív területben helyezkednek el, ezért minden, a thymusból kilépő vagy abba belépő, immunológiailag kompetens sejtnek keresztül kell mennie a keratinnegatív területen. Ez azt sugallja, hogy a keratinnegatív terület a thymus tranzitzónája. A hematoxilin-eozin festés alapján megjelenő kéreg-velő határt nem reprezentálja sejtes háttér, de a keratinpozitív hálózat és a keratinnegatív terület között húzódó határt sejtes összetétele határozza meg (epithelium-mesenchyma). Feltételezzük, hogy a keratinnegatív terület és a keratinpozitív hálózat között lévő határ a thymus valódi szövettani és funkcionális határa. Orv Hetil. 2019; 160(5): 163-171.
\end{abstract}

Kulcsszavak: thymus, kéreg-velő határ, ganglionléc, keratinpozitív hálózat, keratinnegatív terület, Foxn l

\section{Structure of the thymus at the beginning of the 21th century}

The classical histological features of the thymus are the cortex and medulla, the Hassall's bodies as well as the lobules. Anti-pan-cytokeratin immunocytochemistry shows that the keratin staining pattern of the cortical and medullary epithelial cells is different. The medulla is further compartmentalized: it consists of keratin-positive network and keratin-negative areas. Histology of the keratin-negative area is identical with the connective tissue of the septae. The basal lamina is continuous at the capsule and septae, but it becomes discontinuous at the border between the keratinpositive network and keratin-negative area. This immunohistochemical finding is the first histological sign, which may explain that the medulla has no blood-thymus barrier. The supporting tissue of the keratin-negative area is identical with that of the septae. The connective tissue of thymic capsule and septae develops from the cranial neural crest cells, therefore we hypothesize that the keratin-negative area has neural crest origin. Blood vessels of the thymic medulla localize in the keratin-negative area. Every emigrating or immigrating immunologically competent cells should enter the keratin-negative area, therefore this area is the transit zone of the thymus. The hematoxylin-eosin staining of the thymus shows that the thymic cortico-medullary border does not represent cellular background. However, the border between keratin-positive network and keratin-negative area is determined by cellular identity (epithelial and mesenchymal tissues). Therefore, it can be assumed that the real histological and functional border is the border between the keratin-positive network and the keratin-negative area.

Keywords: thymus, cortico-medullary border, neural crest, keratin-positive network, keratin-negative area, Foxn l

Bódi I, H-Minkó K, Prodán Zs, Nagy N, Oláh I. [Structure of the thymus at the beginning of the 21 th century]. Orv Hetil. 2019; 160(5): 163-171.

(Beérkezett: 2018. június 22.; elfogadva: 2018. augusztus 1.)

A szerkesztőség felkérésére készített közlemény. 


\section{Rövidítések}

$\mathrm{ECM}=$ extracelluláris mátrix; GFP = (green fluorescence protein) zöld fluoreszcens protein; $\mathrm{KNA}=$ (keratine-negative area) keratinnegatív terület; $\mathrm{KPN}=$ (keratin-positive network) keratinpozitív hálózat; $\mathrm{MHCII}=$ (major histocompatibility complex II) fő szövet-összeférhetőségi komplex-II; SPB = surfactant protein $\mathrm{B}$

Még a huszadik század első felében is enigmatikus szervnek tekintették a thymust, különféle, sokszor misztikus funkciót tulajdonítottak neki [1], például azt, hogy az örök fiatalság szérumát termeli. Az első tudományos jellegü leírás a XVIII. század elejéről származik, mely szerint a thymus számos részecskét termel, amelyek a nyirokcsomókban találhatókhoz hasonlóak [2]. Több mint 100 évvel később Beard [3] a thymusból és a nyirokcsomókból származó részecskék (lymphocyta, thymocyta) hasonlóságára utalva úgy gondolta, hogy az összes „részecske" a thymusból származik. Ma már tudjuk, hogy a thymocyták periferalizációja szükséges a perifériás nyirokszervek thymusdependens állományának kialakulásához. Bruce Glick 1957-ben megjelent cikkében a madarak Fabricius-bursájának funkcióját ismertette [4], miszerint a B-sejtek felelősek a humorális immunitásért. Kísérletei szerint egynapos korban a Fabricius-bursa kiirtása súlyosan károsítja a csirkék humorális immunitását, azaz antigénspecifikusantitest-termelését.

Nem sokkal később, 1961-ben láttak napvilágot Miller [5] bőrtranszplantációs kísérletei, melyek szerint a heterogén bőrtranszplantátumot a normálegér immunrendszere nem türi meg, kilökődik, azonban a thymusirtott állatok szervezete elfogadja azt. Ezen kísérletek vezettek ahhoz a következtetéshez, hogy a thymus felelős a transzplantációs, vagy celluláris immunitásért. Glick [4] és Miller [5] adatai alapozták meg az immunitás kétsejtes dogmáját (a humorális immunitásért a B-sejtek; a celluláris, transzplantációs immunitásért a T-sejtek a felelősek). Ez a kétsejtes dogma 1974-ben egészült ki és vált teljessé a Steinman által leírt lymphaticus dendritikus vagy akcesszorikus, antigénprezentáló sejtek felfedezésével [6]. Ma már tudjuk, hogy a thymus felelős az úgynevezett centrális toleranciáért, vagyis a saját és az idegen felismeréséért [7-9].

\section{A thymus fejlődése}

A thymus komplexitása, összetett szerkezete már az embrionális fejlődése során is megnyilvánul. Az alapvázát alkotó hámreticulum az előbél endodermájából, a harmadik garattasakból fejlődik. Mintázata kezdetben (csakúgy, mint a tüdő esetében) mirigyes szerkezetű, lebenyes jellegét a későbbiekben is megőrzi [10]. Erre utal magyar neve is, csecsemőmirigy. Embrionális fejlődése során az előbél hámbimbója, majd hámkötege elágazódik, miközben benő a környező mesenchymába, majd kialakul a felnőttformára jellemző kéreg- és velóállomány [11].
A hámeredetű telepét körülvevő mesenchyma a cranialis ganglionléc származéka [12-16], eltérően a perifériás nyirokszervek mesenchymájától, mely mesodermalis eredetű $[17,18]$. A thymust körülvevő mesenchymából alakul ki a tokja és a lebenykéket elválasztó sövények [19, 20]. Ha a cranialis ganglionléc sejtjeinek vándorlása bármi okból hátráltatott vagy elmarad, a thymus fejlődése károsodik [21-23]. Mivel a thymus tokja és sövényei ugyanabból a sejtes forrásból alakulnak ki, mint a szív aorticopulmonalis septuma, a thymus és a szív aorticopulmonalis septumdefektusa gyakran jár együtt [24, 25]. DiGeorge-szindróma esetén a ganglionléc-eredetű sejtek fejlődésének és múködésének zavara lép fel, melynek következtében alulfejlett thymus alakul ki, ami immundeficiens állapothoz vezethet $[26,27]$. Az elágazódó hámkötegek körül kialakuló toknak és a sövényeknek a fejlődésével párhuzamosan a hámkötegeket haemopoeticus eredetú T-sejt-prekurzorok kolonizálják, melyek a tömött hámkötegek köb alakú sejtjeit csillag alakú hámreticulumsejtekké alakítják át. A thymus fent vázolt fejlődését a korábbi szövettani leírások mint thymus epithelialis és thymus lymphaticus foglalták össze [28].

Az előbél endodermájából fejlődő hámkötegek sejtjeiben expresszálódó, a 'forkhead box' transzkripciós családba tartozó Foxnl transzkripciós faktor felelős a thymus hámreticulum-irányú elköteleződéséért. A Foxnl befolyásolja a ganglionléc-eredetû sejtek vándorlását, mesenchymalis sejtekké való differenciálódását, majd a tok és a sövények fibroblasztjaivá való átalakulását is $[29,30]$. Jelenlegi ismereteink szerint a Foxnl szabályozza a thymus vascularisatiójának kialakulását is $[31$, 32].

A hámsejtek differenciálódásához elengedhetetlen feltétel a ganglionléc-eredetû mesenchyma indukciója [29, 36-38]. A vérlemezke-eredetû növekedési faktor (platelet-derived growth factor) receptor-alfa-pozitív mesenchyma hiánya hypoplasticus thymust okoz a csökkent hámproliferáció miatt [38, 39]. A hám további (kérgi és velőhám) differenciálódásához a T-sejtektől származó szignálok is szükségesek [40-41].

A hámsejtek fenotípusa és funkciója alapján megkülönböztetünk kérgi és velőhámsejteket a bennük lévő citokeratin intermedier filamentum alapján. Igaz, a páncitokeratin-antitest felismeri mind a kérgi, mind a velőhámsejteket, de a kettő mintázata olyannyira eltérő, hogy a különbség a kéreg- és a velőállomány között biztonsággal megállapítható.

A hámsejtek eredetérôl eltérő nézetek alakultak ki, hiszen sokáig úgy vélték, hogy a kérgi hámsejtek ectodermalis, míg a velőhámsejtek endodermalis őssejtből fejlődnek $[42,43]$. Eredetüket visszavezetik az úgynevezett unipotens progenitorokra, miszerint a kérgi és a velőhámsejtek külön útvonalon, egymástól függetlenül fejlődnek [44]. A másik elmélet szerint a kérgi és a velőhámsejtek ugyanazon bipotens progenitorokból képződnek [41, 44]. 


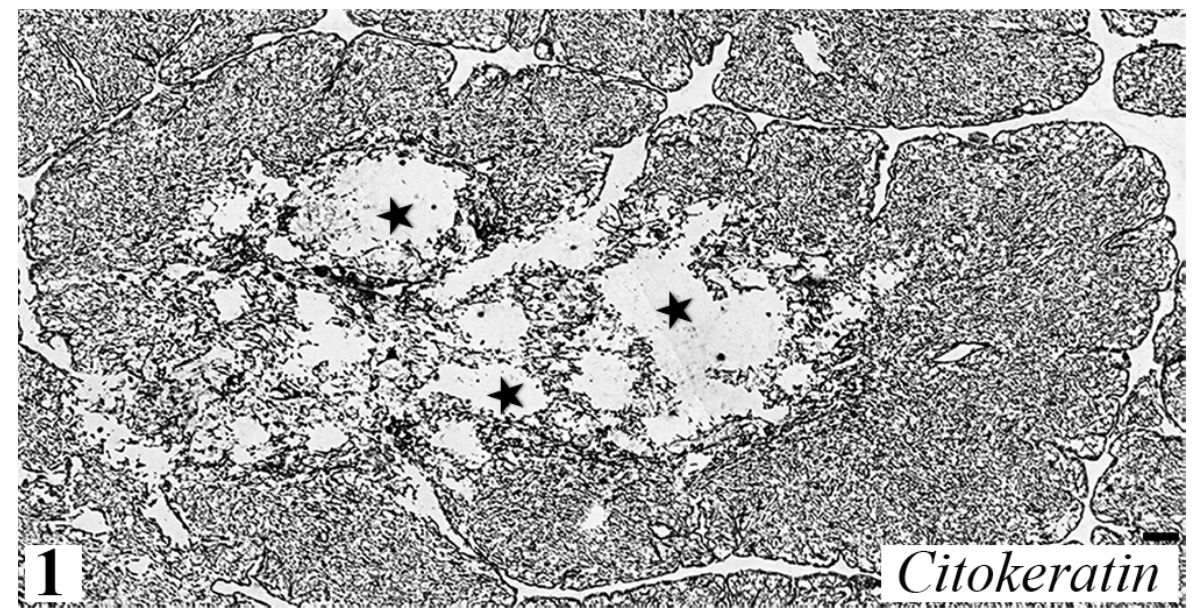

\begin{tabular}{l|l} 
1. ábra & $\begin{array}{l}\text { Csirkethymus: a velóállomány morfometriai vizsgálata alapján mintegy } 50 \% \text {-ban keratinmentes terület } \\
\text { Bar }=100 \mu \mathrm{m}\end{array}$
\end{tabular}

\section{A thymus elemeinek szövettani és embriómanipulációs vizsgálata}

A thymus fejlődésében részt vevő endodermalis eredetû hám és a haemopoeticus elemek (T- és B-lymphocyta, makrofág, dendritikus sejt) tanulmányozására az im-

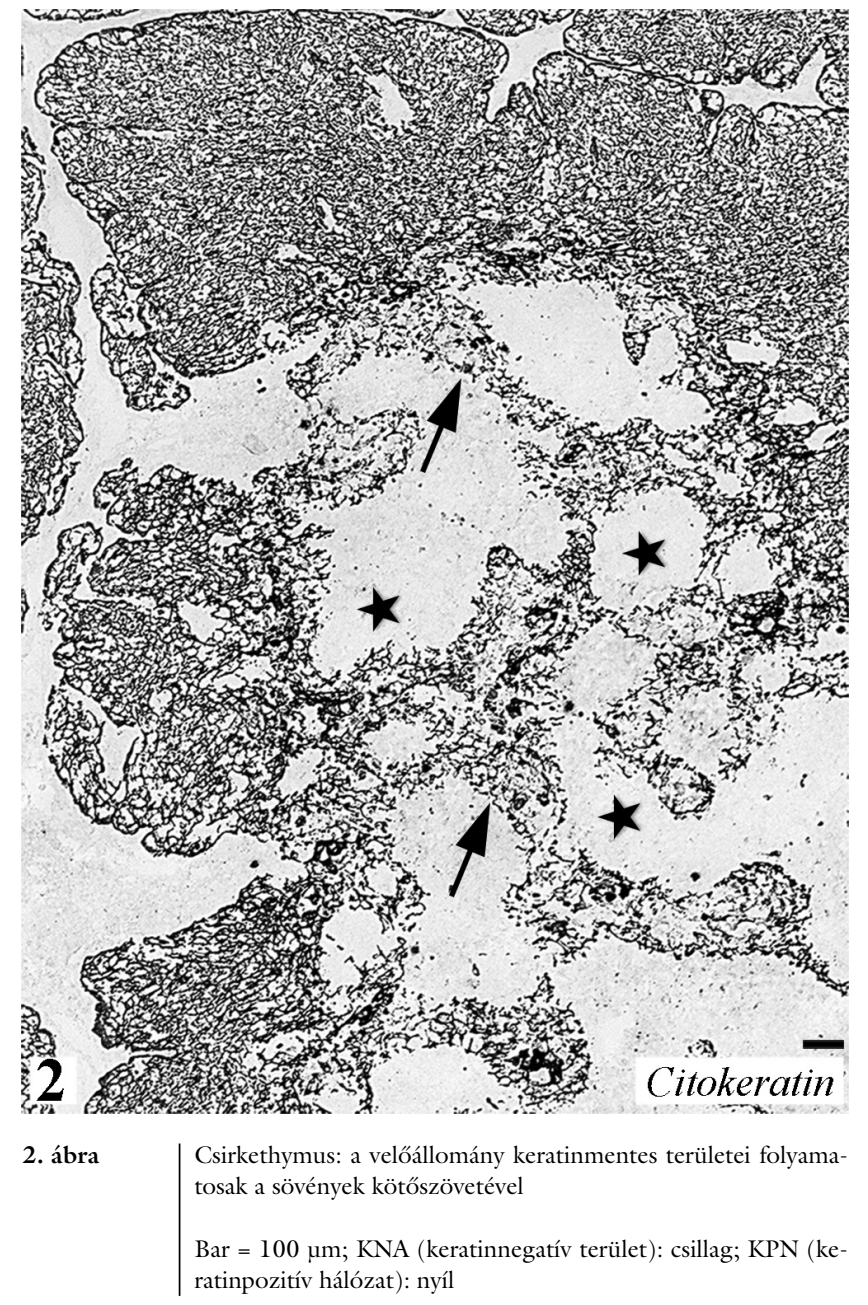

muncitokémiai és immunfluoreszcens módszerek alkalmasak. A harmadik komponensnek, a ganglionléc-eredetű sejteknek a migrációját embriómanipulációs technikával tanulmányozhatjuk, mivel a ganglionlécsejt-specifikus antigének expressziója a sejtek vándorlása során lecseng, ezért a sejtek identifikálása nem lehetséges korai ganglionléc markerekkel. Embriómanipulációs munkánk célja vizsgálni, hogy a tok és a sövények elemei mellett a ganglionlécsejtek részt vesznek-e a thymus velő́llományának kialakításában, ami lehetőséget nyújt a humán thymus morfológiai jellegzetességeinek és fejlődési anomáliáinak meghatározásában. Egyrészt a cranialis ganglionléc eltávolításának hatását vizsgáljuk, másrészt kiméra csirkeembriók létrehozásával transzgenikus, green fluorescence proteint (GFP) expresszáló „zöld” csirkeembriók felhasználásával követjük nyomon a ganglionlécsejtek vándorlását. Kiméra állatban a GFP-embrióból származó transzplantált ganglionlécsejtek zölden fluoreszkálnak, így biztonsággal identifikálhatók.

A madárthymusok mellett lehetőségünk nyílt humán thymusok vizsgálatára is. Munkacsoportunk a Gottsegen György Országos Kardiológiai Intézettel klinikai együttmúködésben áll, melynek keretében csecsemő- és gyermekthymusok vizsgálatával is foglalkozik (TUKEBszám: 158/2017).

\section{A velőállomány kompartmentalizációja}

A csirke- és a humán thymus szövettani képe a klasszikus hematoxilin-eozin festéssel kéreg- és velőállományra különül. A hámspecifikus anticitokeratin immuncitokémiai festések morfometriai vizsgálata kimutatta, hogy a madárthymus velóállománya mintegy fele-fele arányban keratinpozitív hálózatra (keratin-positive network, KPN) és keratinnegatív területre (keratine-negative area, KNA) tagolódik (1.ábra). A KPN összeköttetésben áll a kéregállomány hámreticulumával, míg a KNA folyamatos a sövények kötőszövetével (2. ábra). Az anticitokeratin 


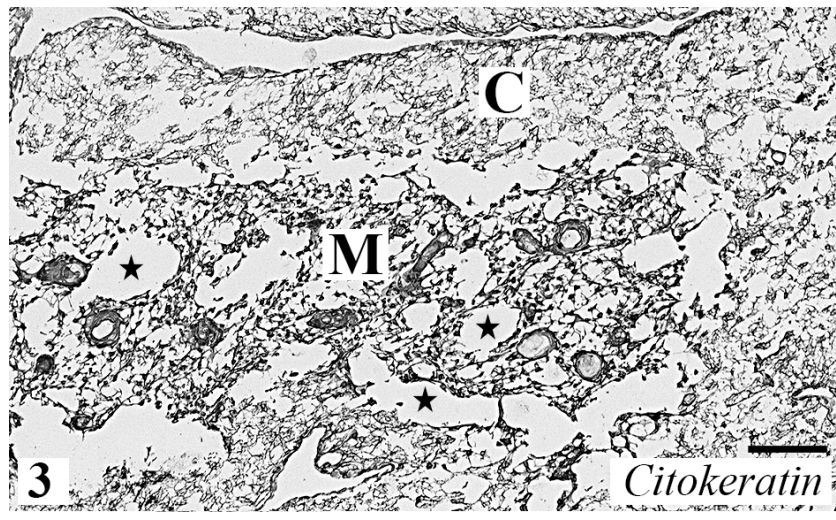

3. ábra $\quad$ Humán thymus: a kéreg-velő határt keratinmentes állomány rajzolja körül

Bar =100 $\mu \mathrm{m} ; \mathrm{C}=$ cortex; KNA (keratinnegatív terület): csillag; $\mathrm{M}=$ medulla

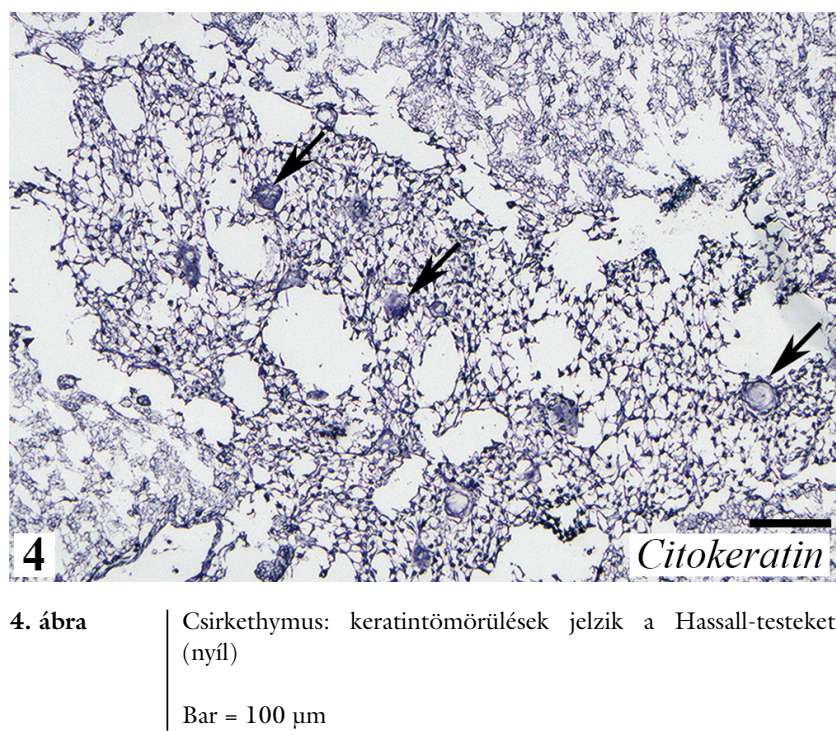

immuncitokémiai festés humán thymuson (3. ábra) is igazolta, hogy a KPN és a KNA jelenléte nem csirkespecifikus. Morfometriai vizsgálat nélkül is látszik, hogy a humán thymus velóállományában a KPN területe nagyobb, mint a velő $50 \%$-a, de ugyanúgy összeköttetésben áll a kéregállomány hámreticulumával, mint a csirke esetében [33]. Említésre méltó, hogy a humán thymusban a keratinnegatív területek a kéreg-velő határon folyamatosak, körülhatárolva a velőállomány hámreticulumát (3. ábra), ami csirkethymusban nem figyelhető meg. A citokeratin-immunfestés során a KPN-ben Hassall-testek és ciszták találhatók (4. és 5. ábra). A Hassall-testek epithelsejtjei hagymalevélszerúen összetömörödnek [45], míg egyes cisztákban mikrobolyhok és/vagy mérsékelten elektronsứrü anyag található. A thymus hámtelepe az előbélből fejlődik, mint a légutak és az alveolusok hámja, ezért nem meglepő, hogy a KPN-ben kialakuló cisztákat alkotó sejtek citoplazmájában a tüdő II. típusú pneumocytáira jellemző, myelinszerű struktúra látható (6. ábra); az immuncitokémiai vizsgálatok szerint a sejtek MHCII-

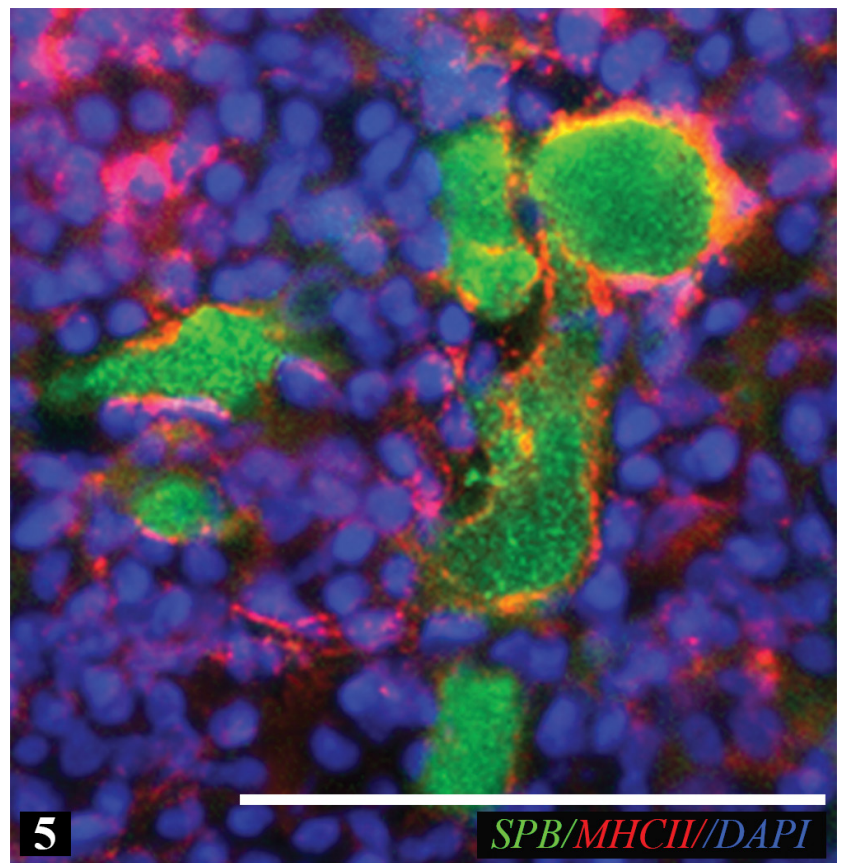

5. ábra

Csirkethymus: MHCII-pozitív hámsejtek (piros) alkotta ciszták üregét surfactant $(\mathrm{SPB}$, zöld) tölti ki.

Bar $=100 \mu \mathrm{m} ; \mathrm{MHC}=$ fó szövet-összeférhetőségi komplex

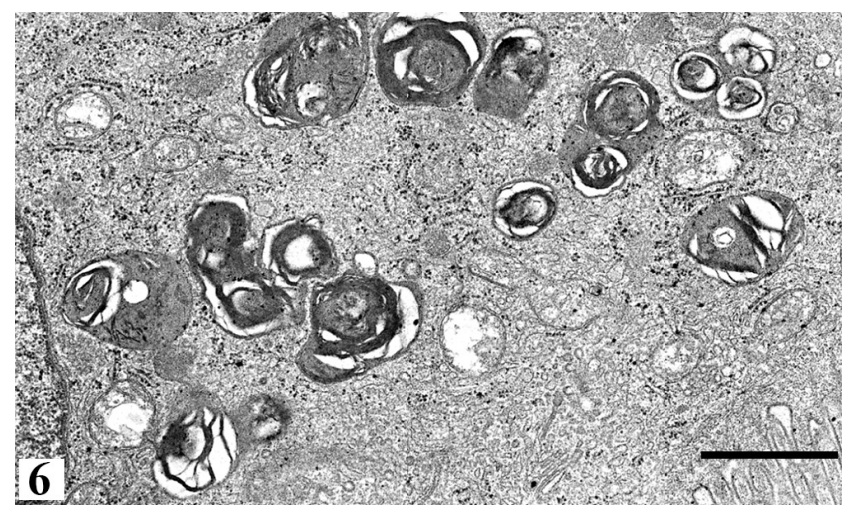

6. ábra

Csirkethymus: elektronmikroszkópos felvétel ciszta falát alkotó hámsejtekről. Foszfolipidtartalmú myelinstruktúrák

Bar $=100 \mu \mathrm{m}$

pozitívak, és egyes cisztákban surfactant található (5. ábra). A tüdő II. típusú pneumocytái surfactant B-t (SPB) is termelnek, ami a tubularis myelin alkotója [46]. A ciszták ultrastrukturális morfológiája alapján - myelinszerü képletek a citoplazmában -, valamint annak ismeretében, hogy a ciszták szövetspecifikus antigéneket is termelhetnek [47], többek között SPA-t és SPB-t, megvizsgáltuk, hogy a cisztákban képződik-e SPA és/vagy SPB. A ciszták immunmorfológiai karakterizálása során kimutattuk, hogy az emlős irodalommal megegyezően [47] a madárthymus cisztáit alkotó hámsejtek is MHCII-pozitívak, és számos cisztában találtunk szekretált surfactant molekulákat. A csirkék dexametazonkezelése T-lymphocyta-depletiót okoz, ami a surfactant B-t 


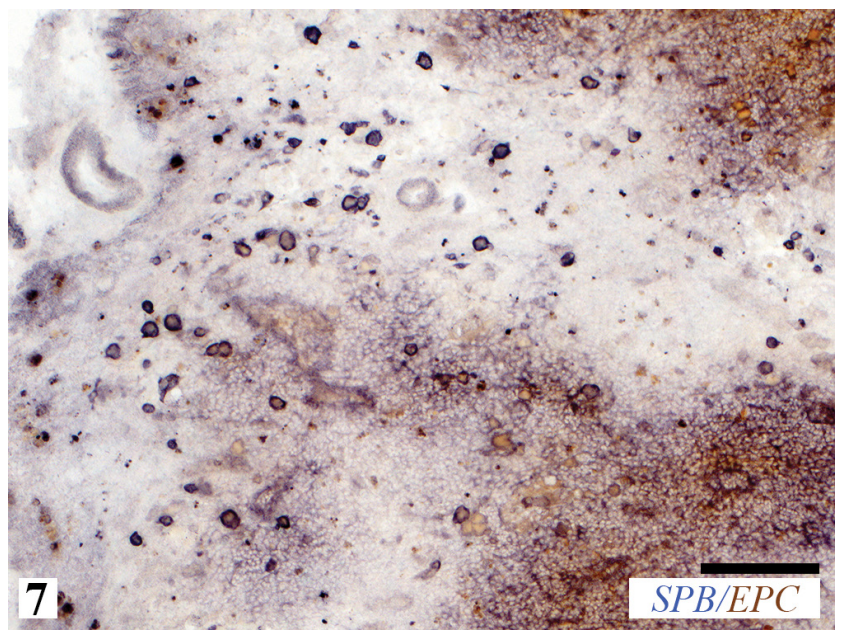

7. ábra | Csirkethymus: dexametazonkezelés. A surfactant B-t termeló hámsejtek dexametazonrezisztensek. Az SPB-pozitív sejtek száma jelentős a thymusban. A barna színreakció az endogénperoxidáz (EPC)-aktivitást mutatja

Bar $=100 \mu \mathrm{m} ; \mathrm{SPB}=$ surfactant protein $\mathrm{B}$

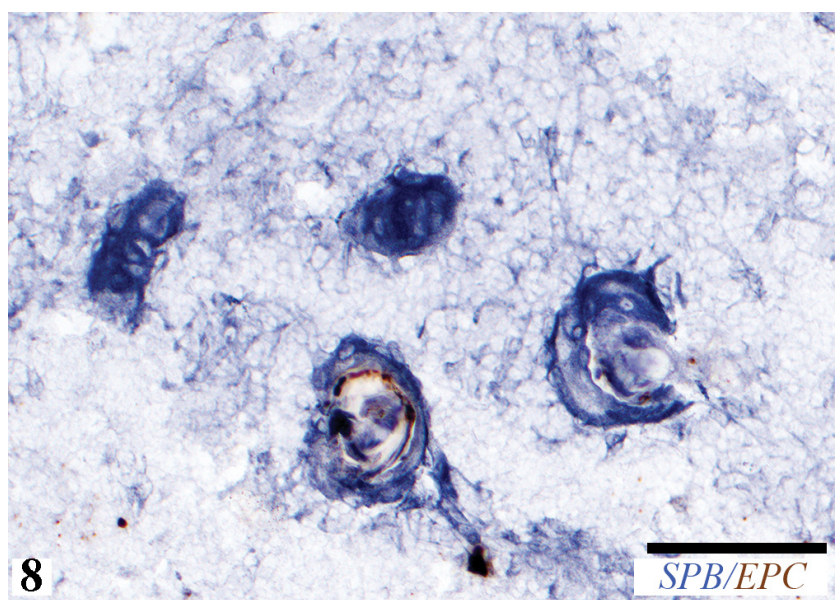

8. ábra

$$
\begin{aligned}
& \text { Humán thymus: surfactant B-t (SPB) termelő hámsejtek. A bar- } \\
& \text { na színreakció az endogénperoxidáz-aktivitást mutatja } \\
& \text { Bar }=100 \mu \mathrm{m}
\end{aligned}
$$

termelő sejtek számát relatív módon megemeli, jelezvén a sejtek funkcionális aktivitását és szteroidrezisztenciáját (7. ábra). Az SPB-pozitív sejtek humán thymusban is kimutathatók (8.ábra).

\section{A keratinnegatív területek szövettana és összetétele}

A KNA támasztószövete reticularis kötőszövet, amely folyamatos a sövények kötószövetével (9. ábra). $\mathrm{Ez}$ a szövettani kép összecseng az anticitokeratin-festés eredményével, amennyiben a KNA összefügg a sövényekkel (2. ábra). A thymus kéregállománya olyan mikrokörnyezetet biztosít a thymocyták számára, amelyben különböző citokinek, kemokinek hatására differenciálódnak.

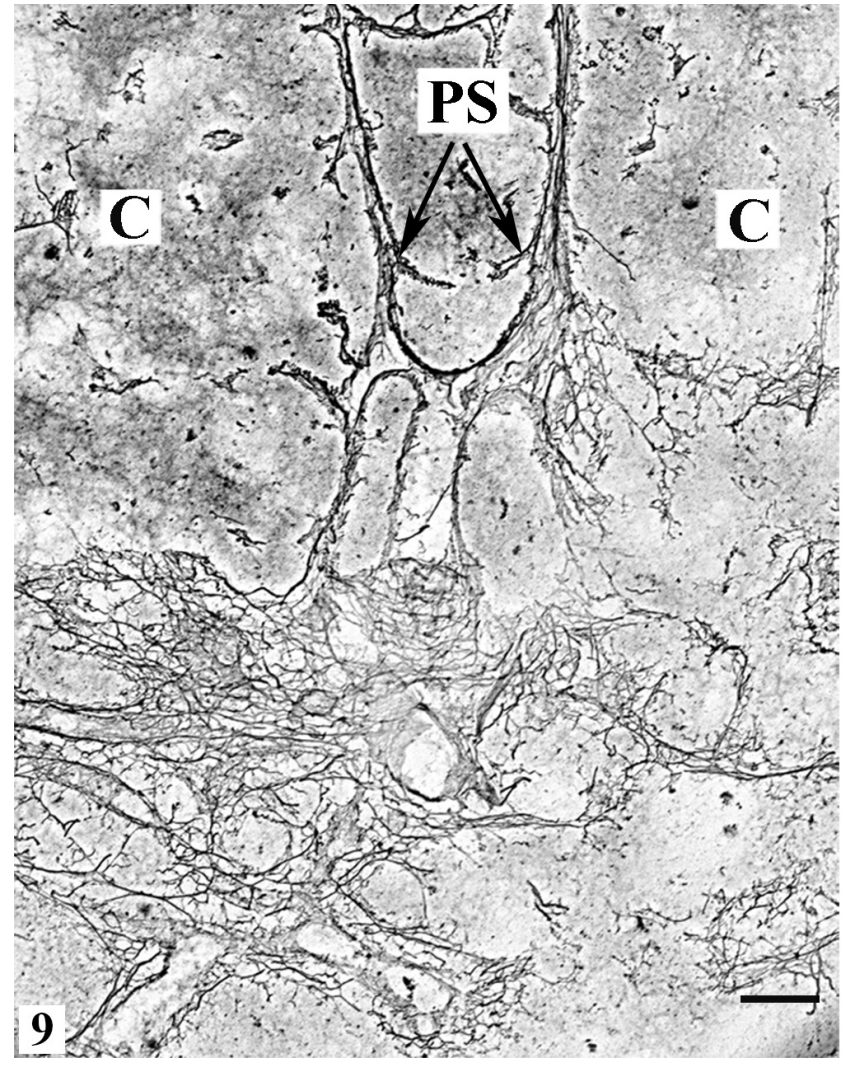

9. ábra

$$
\begin{aligned}
& \text { Csirkethymus: ezüstimpregnáció. A KNA alapszövete reticularis } \\
& \text { kötőszövet, mint a perifériás nyirokszerveké } \\
& \text { Bar }=100 \mu \mathrm{m} ; \mathrm{C}=\text { kéregállomány; KNA = keratinnegatív terü- } \\
& \text { let; PS = primer sövények (nyíl) }
\end{aligned}
$$

A fejlődési folyamatokon, szelekciókon átjutó érett Tsejtek a velóállományba vándorolnak, majd onnan az ereken keresztül jutnak a perifériára. A T-sejtek 'közlekedését' az extracelluláris mátrix (ECM) molekulái irányítják. A fibrocyták fibronektint, tenaszcint, laminint, kolla-

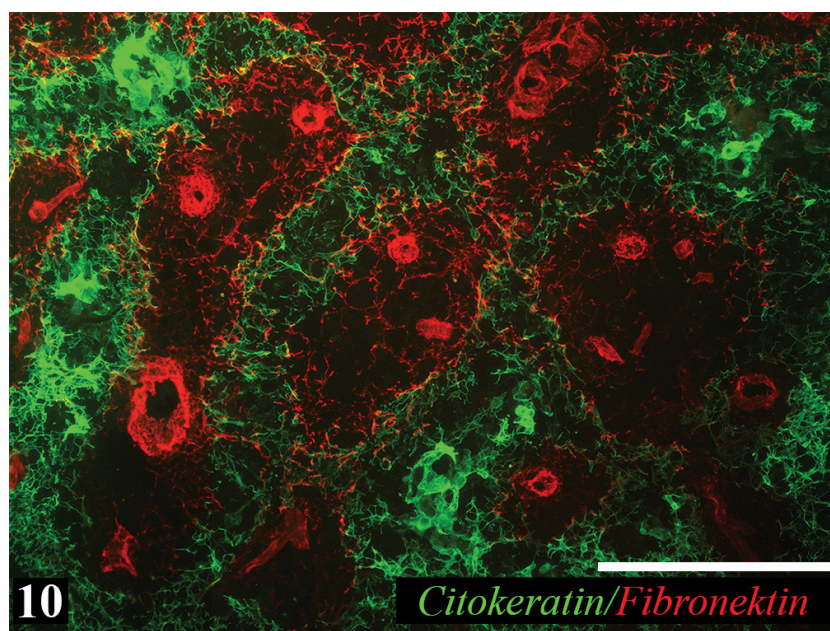

10. ábra Csirkethymus: a fibronektin (zöld) kizárólag a KNA-ra korláto zódik. Citokeratin: piros

Bar $=100$ um; KNA = keratinnegatív terület 


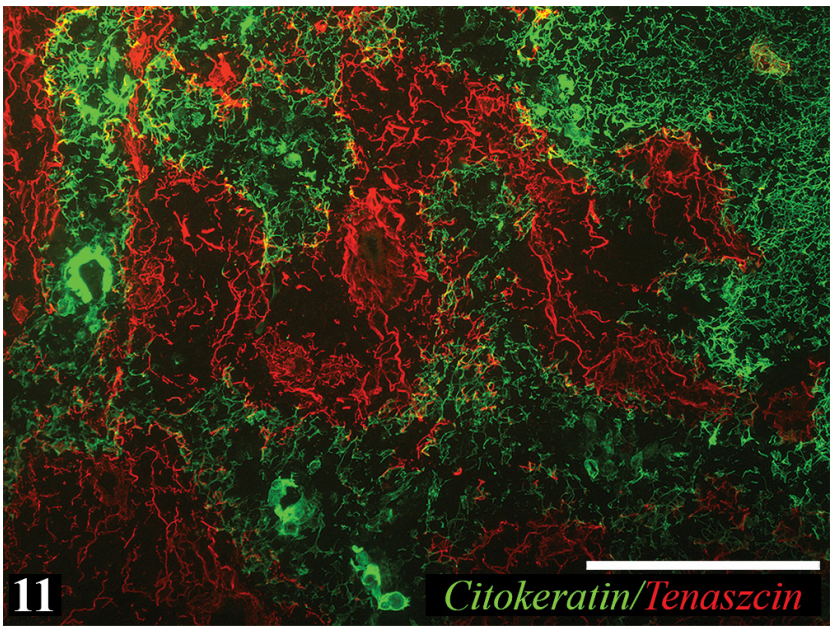

11. ábra

Csirkethymus: tenaszcin (zöld) is a KNA-ban található. Citokeratin: piros

Bar $=100 \mu \mathrm{m} ; \mathrm{KNA}=$ keratinnegatív terület

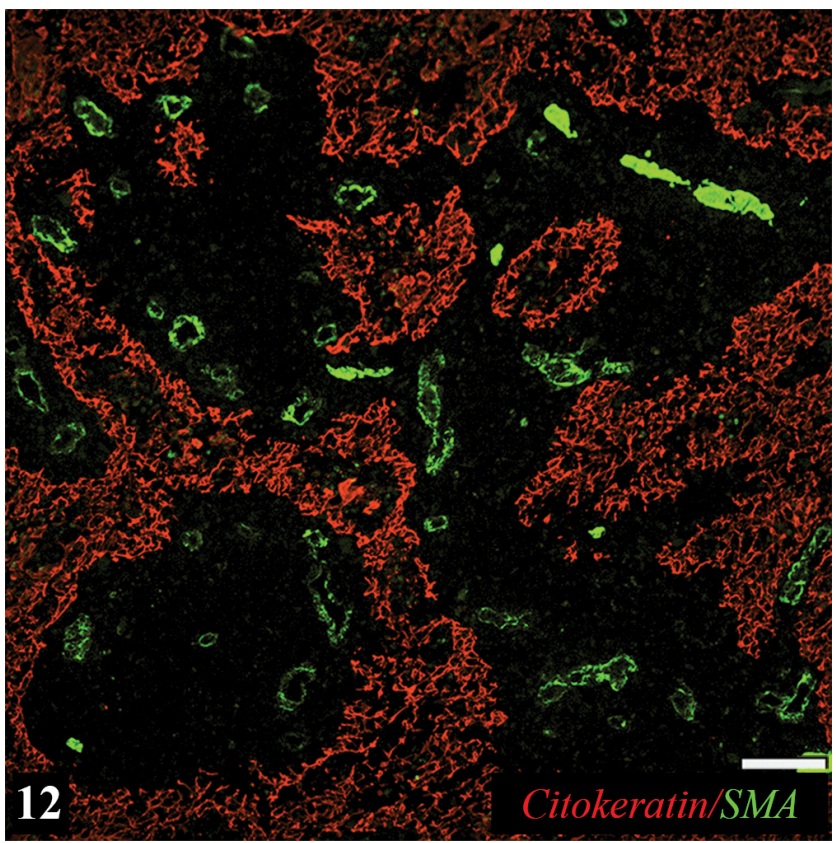

12. ábra

Csirkethymus: az anti-simaizomaktin a kisartériák és prekapillárisok simaizomzatát (zöld) mutatja. Az erek a KNA-ban lokalizálódnak. Citokeratin: piros

Bar $=100 \mu \mathrm{m} ; \mathrm{KNA}=$ keratinnegatív terület

gént termelnek, melyek befolyásolják a lymphocyták vándorlását és differenciálódását [48]. Ezért tanulmányoztuk az ECM-ot alkotó két esszenciális molekula, a fibronektin (10. ábra) és a tenaszcin (11. ábra) megjelenését. A citokeratin- és fibronektinpozitív (10. ábra), valamint citokeratin- és tenaszcinpozitív (11. ábra) kettős immunfestések világosan mutatják, hogy az ECM expressziója a velóállományban lévő KNA-ra korlátozódik, ahol a velőállomány vérerei találhatók (12. és 13. ábra).

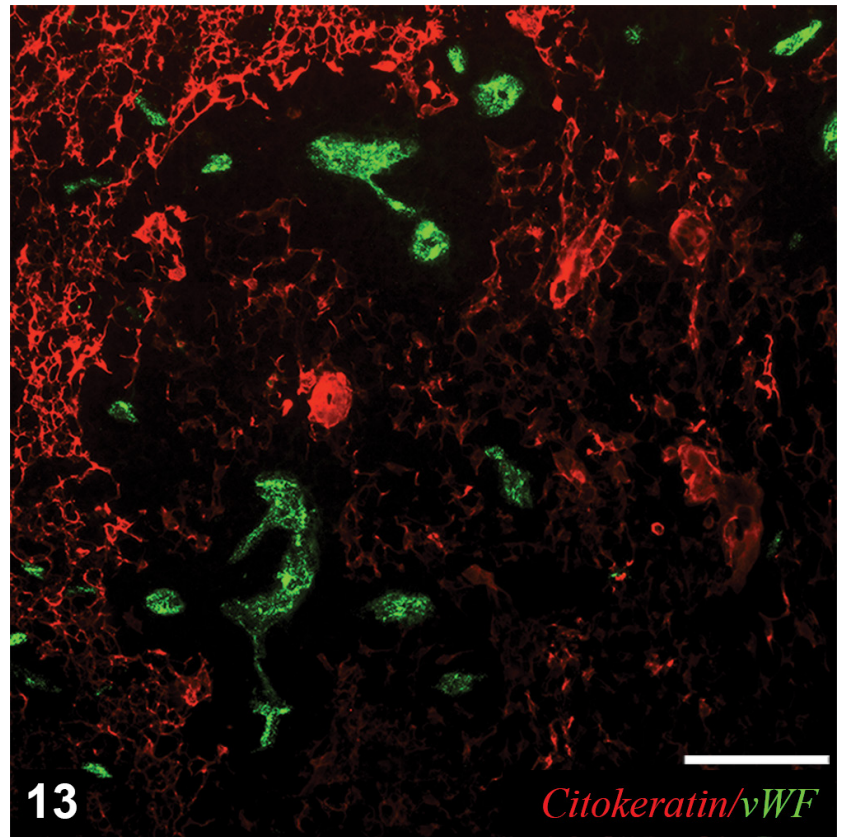

13. ábra

Humán thymus: a von Willebrand-faktor (vWF) (zöld) immuncitokémiája az endothelsejtekben. Citokeratin: piros

Bar $=100 \mu \mathrm{m}$

\section{A KPN és a KNA határa mint funkcionális határfelület a thymusban}

A thymus erei a tok és a sövények állományán keresztül jutnak el a velő́llomány keratinnegatív területeire, ami azt jelenti, hogy a thymusból kilépő vagy oda bevándorló sejteknek be kell lépniük a KNA területére. Az intenzív sejtvándorlás indokolja a KNA jelentős mértékét. A thymus velőállományának vascularis hálózata, mint fentebb említettük, kizárólag a KNA-ban helyezkedik el, amit az erek simaizomsejtjeiben lévő simaizomaktin (12. ábra) és az endothelsejtekben expresszálódó von Willebrand-faktor igazol (13. ábra). A thymus velőállományának erei, ahol az immunkompetens T-lymphocyták elhagyják a thymust, a KNA-ban helyezkednek el, ezért a migráló sejteknek a KPN-ból be kell lépniük a KNA-ba. A klasszikus, hematoxilin-eozin festéssel látható kéregvelő határ jelentősen kisebb „felület”, mint az a határfelület, amely a KPN és a KNA között van. A thymus dendritikus sejtjei, a T-sejtek szelekciójának részesei, az erek körül a KNA-ban helyezkednek el, ami arra utalhat, hogy a valódi sejtes és funkcionális határt a KPN-KNA határ jelenti [33].

A kérgi hámsejtek felszínét folyamatos bazális membrán fedi, amely a hámsejteket elválasztja a tok és a sövény kötőszövetétôl. A bazális membrán alkotói közé tartozik a laminin, amely az embrionális életben az egyik elsőként megjelenő ECM-glikoprotein. Az antilaminin immuncitokémiai festés azt mutatja, hogy a bazális membrán a tok alatt és a sövényekben folyamatos, míg a keratinnegatív területeket elérve szaggatottá válik (14. ábra). Az 


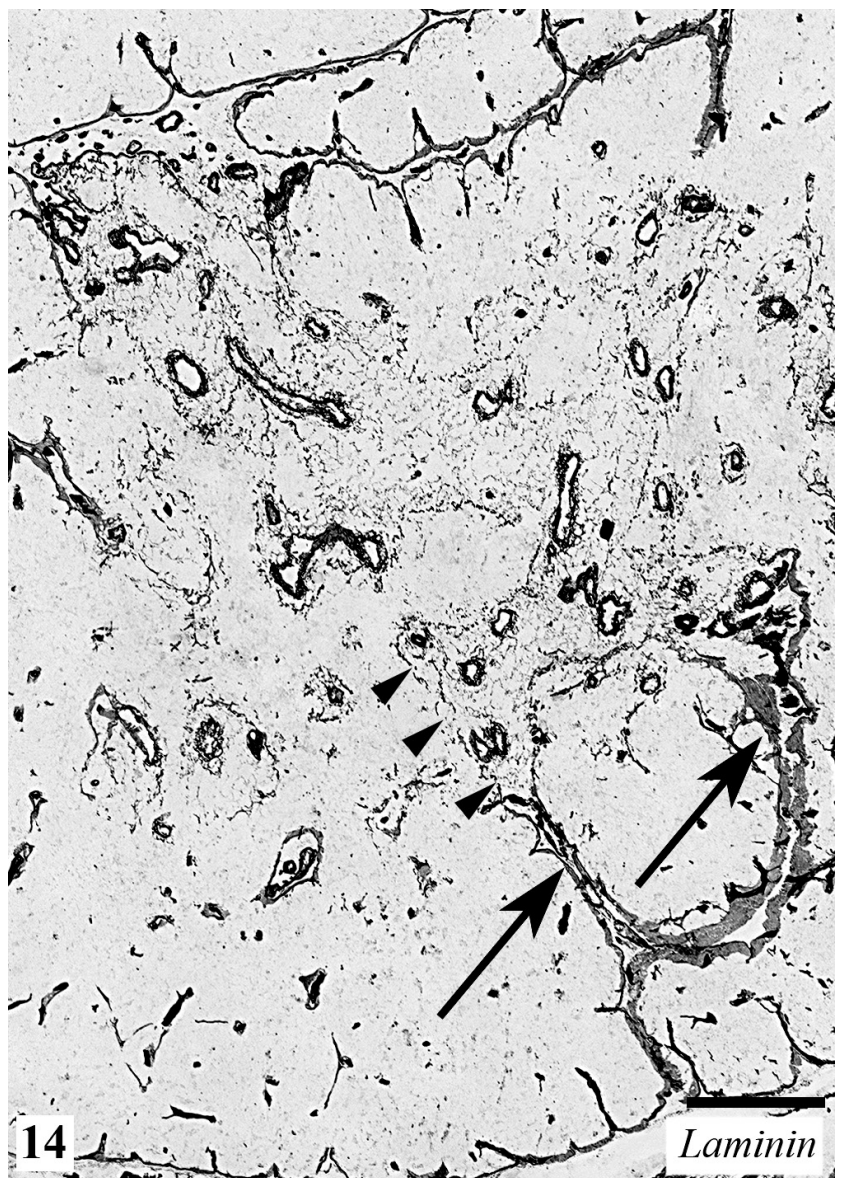

14. ábra Csirkethymus: az antilaminin immuncitokémiai festés mutatja hogy a sövények felszínén a bazális membrán folyamatos (nyíl), míg a KNA-KPN határán szaggatottá válik (nyílhegy)

Bar $=100 \mu \mathrm{m} ; \mathrm{KNA}=$ keratinnegatív terület $; \mathrm{KPN}=$ keratinpozitív hálózat

antilaminin immunfestés a KNA-KPN határon finom „pöttyözött” megjelenést mutat (14. és 15. ábra). Ez az egyetlen olyan hisztológiai adat, amely bizonyítja a thymus-vér barrier hiányát.

\section{A Foxnl transzkripciós faktor expressziója és szabályozó szerepe}

A Foxnl transzkripciós faktor megjelenése a harmadik garattasak ventralis részének hámsejtjeiben jelzi ezen sejtek thymushámsejtté való elkötelezettségét [29]. A Foxn l-pozitív hámsejtek befolyásolják a cranialis ganglionlécsejtek vándorlását a thymus hámtelepe köré és fibroblasztokká differenciálódásukat, kialakítva a tok és a sövények kötőszövetét [24]. Jelenlegi ismereteink szerint a Foxn l-nek szabályozó szerepe van a thymus vascularisatiójának kialakulásában is $[31,32]$. A Foxnl transzkripciós faktor a thymus hámsejtjeire jellemző (16. ábra), azonban a kettős immuncitokémiai festés (citokeratin és Foxnl) azt mutatta, hogy egyrészt a KNA-ban levő sejtek is expresszálják ezt a molekulát (17. ábra), másrészt a thymus kisartériáinak és prekapillárisainak simaizom-

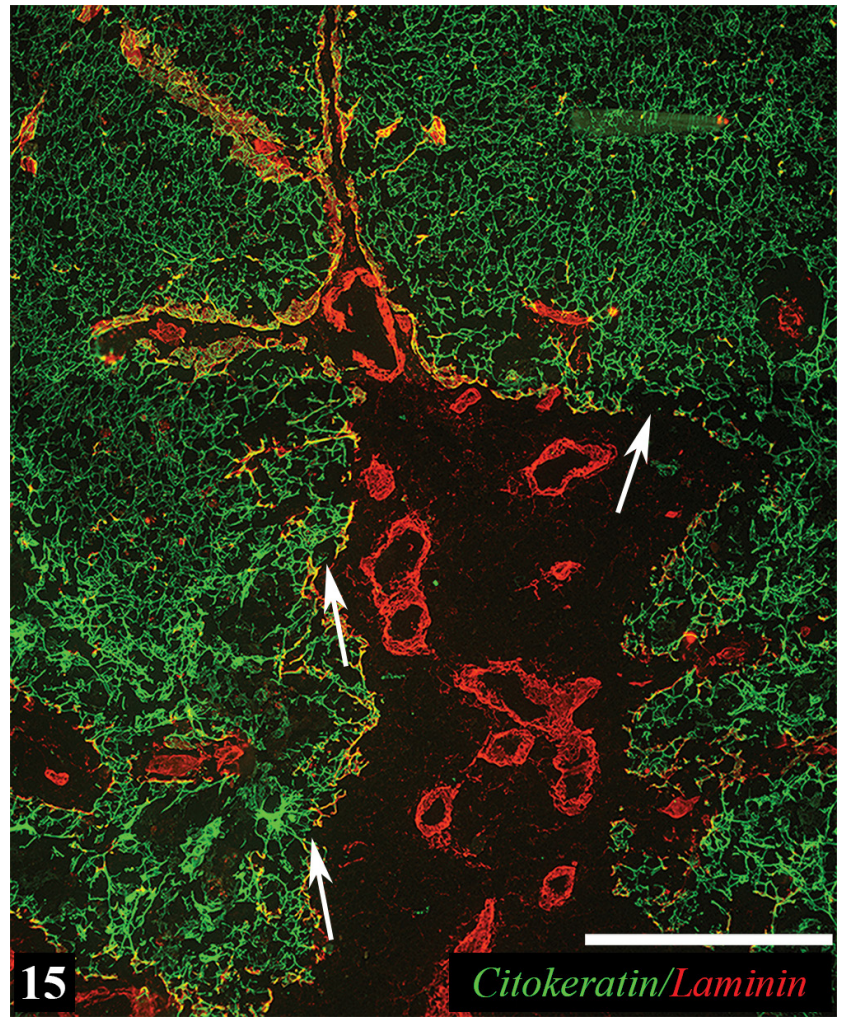

15. ábra Csirkethymus: anticitokeratin (zöld) és antilaminin (piros) kettős immunfluoreszcens festéssel az erek a KNA-ban találhatók. A nyíl a felszakadozott bazális membránt mutatja

Bar $=100 \mu \mathrm{m} ; \mathrm{KNA}=$ keratinnegatív terület

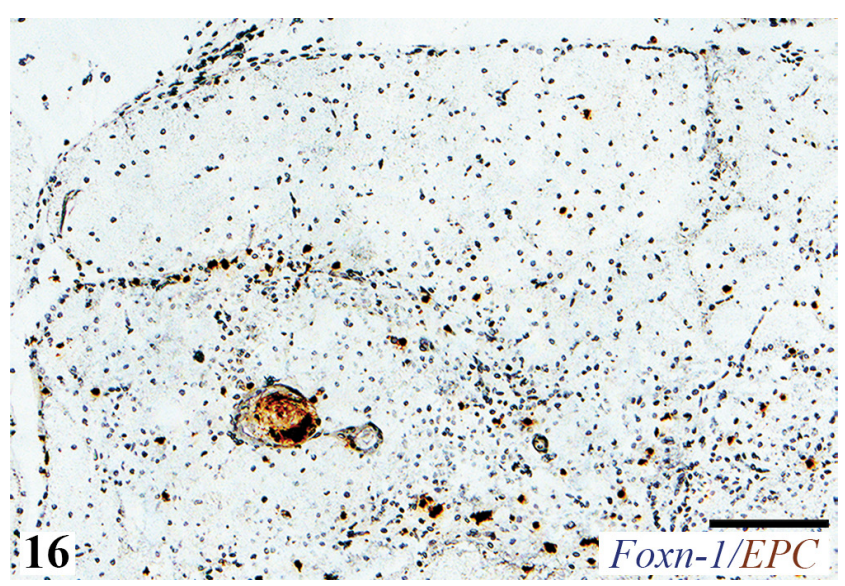

16. ábra $\mid$ Humán thymus: a Foxnl transzkripciós faktor expressziója. A barna színreakció az endogénperoxidáz-aktivitást mutatja

Bar $=100 \mu \mathrm{m}$

sejtjeiben is megjelenik (18. ábra). Ennek alapján feltételezzük, hogy a KNA-ban is vannak hámsejtek, amelyek vagy nem expresszálnak citokeratint (páncitokeratin-ellenes antitestet használtunk), vagy talán az anti-páncitokeratinnal sem kimutatható keratint termelnek. Habár az embriogenezis során számos sejt, többek között a máj, a tüdő, a vese és a húgyutak mesenchymalis és epithelsejt- 


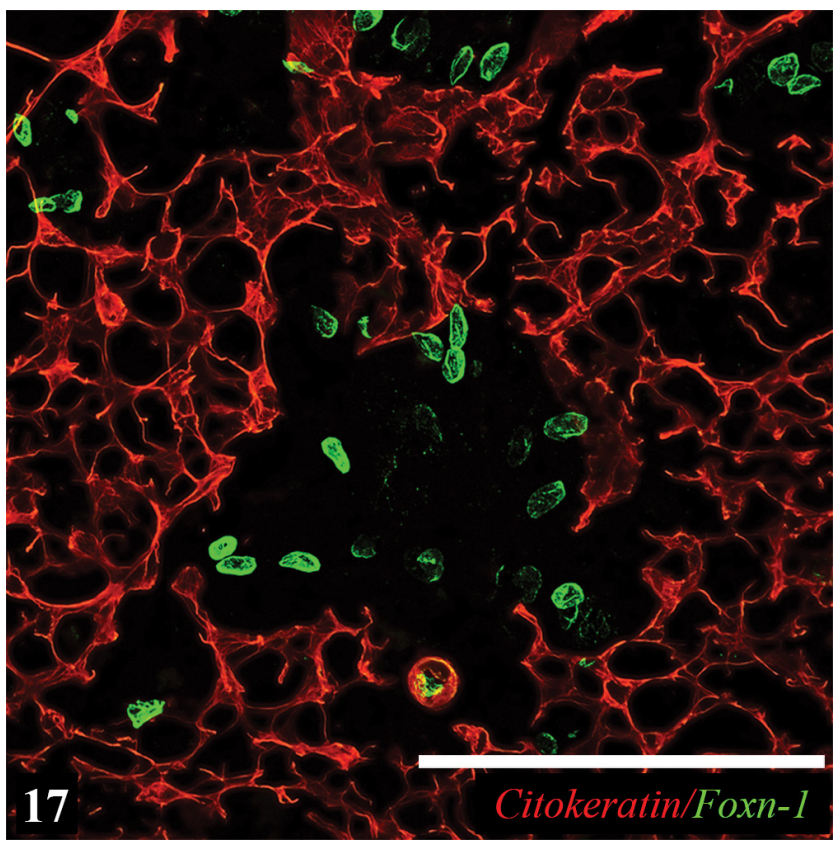

17. ábra | Humán thymus: citokeratin (piros), Foxnl (zöld). A kettős festés azt mutatja, hogy a Foxnl transzkripciós faktor a KNA-ban is expresszálódik

Bar $=100 \mu \mathrm{m} ; \mathrm{KNA}=$ keratinnegatív terület

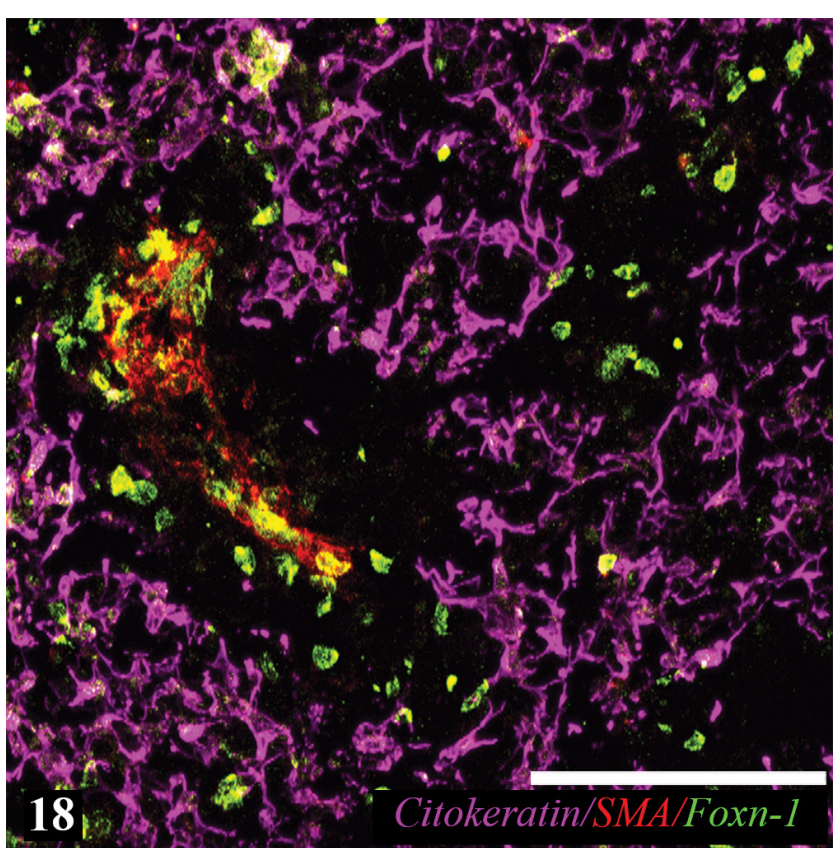

18. ábra

Humán thymus: a KNA-ban található erek falában lévő alfa-simaizomaktin-pozitív sejtek (piros) Foxnl-et (zöld) expresszálnak. Citokeratin: magenta

Bar $=100 \mu \mathrm{m} ; \mathrm{KNA}=$ keratinnegatív terület

jei is expresszálják a Foxnl transzkripciós faktort [49], humán adatokról nem számol be az irodalom.

Jövőbeli munkánk az általunk leírt KPN-KNA funkcionális határ megismerésére fektet hangsúlyt, és a velőállomány keratinmentes területeinek ganglionléc-eredetét tervezzük igazolni, valamint a KNA-ban található Foxnl-pozitív sejtek hovatartozását szeretnénk kimutatni. A KNA a thymusnak a sejtvándorlás szempontjából tranzitzónája, és mint ilyen, a perifériás nyirokszervekkel való kapcsolat fenntartásáért lehet felelős.

Anyagi támogatás: A kutatómunka és a kézirat elkészítése anyagi támogatásban nem részesült.

Szerzői munkamegosztás: B. I.: A thymusminták metszése, immuncitokémiai festése, képfeldolgozás és kiértékelés, a kézirat megírása. H.-M. K.: Athymusok beágyazása, fixálása és az immuncitokémiai eredmények kiértékelése. N. N.: A csirke- és humánadatok összehasonlításában és az adatok szöveges terjesztésében segített. P. Zs.: A szívmütétek során eltávolította a humán thymusokat, valamint az irodalmazásban segített. O. I.: A projekt múködését irányította, és szellemi munkájával hozzájárult az eredmények hiteles publikálásához és a közlemény megírásához. A cikk végleges változatát valamennyi szerző elolvasta és jóváhagyta.

Érdekeltségek: A szerzőknek nincsenek érdekeltségeik.

\section{Irodalom}

[1] Varga I, Uhrinova A, Toth F, et al. Assessment of the thymic morphometry using ultrasound in full-term newborns. Surg Radiol Anat. 2011; 33: 689-695.

[2] Hewson W. Experimental enquiries: part the third. T. Longman, London, 1777.

[3] Beard J. The true function of the thymus. Lancet 1899; 153: 144-146.

[4] Glick B. Experimental modification of the growth of the bursa of Fabricius. Poultry Sci. 1957; 36: 18-23.

[5] Miller DG, Lizardo JG, Snyderman RK. Homologous and heterologous skin transplantation in patients with lymphomatous disease. J Natl Cancer Inst. 1961; 26: 569-583.

[6] Steinman RM, Cohn ZA. Identification of a novel cell type in peripheral lymphoid organs of mice. II. Functional properties in vitro. J Exp Med. 1974; 139: 380-397.

[7] Csaba G. The immunoendocrine thymus as a pacemaker of lifespan. Acta Microbiol Immunol Hung. 2016; 63: 139-158.

[8] Alves NL, Takahama Y, Ohigashi I, et al. Serial progression of cortical and medullary thymic epithelial microenvironments. Eur J Immunol. 2014; 44: 16-22.

[9] Alexandropoulos K, Danzl NM. Thymic epithelial cells: antigen presenting cells that regulate $\mathrm{T}$ cell repertoire and tolerance development. Immunol Res. 2012; 54: 177-190.

[10] Muñoz JJ, Cejalvo T, Tobajas E, et al. 3D immunofluorescence analysis of early thymic morphogenesis and medulla development. Histol Histopathol. 2015; 30: 589-599.

[11] Varga I, Pospisilova V, Jablonska-Mestanova V, et al. The thymus: picture review of human thymus prenatal development. Bratisl Lek Listy 2011; 112: 368-376.

[12] Manley NR, Blackburn CC. A developmental look at thymus organogenesis: where do the non-hematopoietic cells in the thymus come from? Curr Opin Immunol. 2003; 15: 225-232.

[13] Nowell CS, Farley AM, Blackburn CC. Thymus organogenesis and development of the thymic stroma. Methods Mol Biol. 2007; 380: 125-162.

[14] Boehm T. Thymus development and function. Curr Opin Immunol. 2008; 20: 178-184. 
[15] Gordon J, Manley NR. Mechanisms of thymus organogenesis and morphogenesis. Development 2011; 138: 3865-3878.

[16] Varga I, Pospisilova V, Gmitterova K, et al. The phylogenesis and ontogenesis of the human pharyngeal region focused on the thymus, parathyroid, and thyroid glands. Neuro Endocrinol Lett. 2008; 29: 837-845.

[17] Moore MA. Commentary: the role of cell migration in the ontogeny of the lymphoid system. Stem Cells Dev. 2004; 13: 1-21.

[18] Burn SF, Boot MJ, de Angelis C, et al. The dynamics of spleen morphogenesis. Dev Biol. 2008; 318: 303-311.

[19] Foster K, Sheridan J, Veiga-Fernandes H, et al. Contribution of neural crest-derived cells in the embryonic and adult thymus. J Immunol. 2008; 180: 3183-3189.

[20] Müller SM, Stolt CC, Terszowski G, et al. Neural crest origin of perivascular mesenchyme in the adult thymus. J Immunol. 2008; 180: 5344-5351.

[21] Bockman DE, Kirby ML. Dependence of thymus development on derivatives of the neural crest. Science 1984; 223: 498-500.

[22] Bockman DE, Kirby ML. Neural crest interactions in the development of the immune system. J Immunol. 1985; 135: 766s768 s.

[23] Bockman DE, Kirby ML. Neural crest function in thymus development. Immunol Ser. 1989; 45: 451-467.

[24] Jiang X, Rowitch DH, Soriano P, et al. Fate of the mammalian cardiac neural crest. Development 2000; 127: 1607-1616.

[25] Hutson MR, Kirby ML. Model systems for the study of heart development and disease. Cardiac neural crest and conotruncal malformations. Semin Cell Dev Biol. 2007; 18: 101-110.

[26] Wilson DI, Burn J, Scambler P, et al. DiGeorge syndrome: part of CATCH 22. J Med Genet. 1993; 30: 852-856.

[27] Jerome LA, Papaioannou VE. DiGeorge syndrome phenotype in mice mutant for the T-box gene, Tbxl. Nat Genet. 2001; 27: 286-291.

[28] Liu D, Ellis H. The mystery of the thymus gland. Clin Anat. 2016; 29: 679-684.

[29] Neves H, Dupin E, Parreira L, et al. Modulation of Bmp4 signalling in the epithelial-mesenchymal interactions that take place in early thymus and parathyroid development in avian embryos. Dev Biol. 2012; 361: 208-219.

[30] Darnell DK, Zhang LS, Hannenhalli S, et al. Developmental expression of chicken FOXNI and putative target genes during feather development. Int J Dev Biol. 2014; 58: 57-64.

[31] Mori K, Itoi M, Tsukamoto N, et al. Foxnl is essential for vascularization of the murine thymus anlage. Cell Immunol. 2010; 260: 66-69.

[32] Bryson JL, Griffith AV, Hughes B 3rd, et al. Cell-autonomous defects in thymic epithelial cells disrupt endothelial-perivascular cell interactions in the mouse thymus. PLoS ONE 2013; 8: e65196.

[33] Bódi I, Minkó K, Molnár D, et al. A novel aspect of the structure of the avian thymic medulla. Cell Tissue Res. 2015; 359: 489501.

[34] Katakai T, Suto H, Sugai M, et al. Organizer-like reticular stromal cell layer common to adult secondary lymphoid organs. J Immunol. 2008; 181: 6189-6200.
[35] Steiniger BS. Human spleen microanatomy: why mice do not suffice. Immunology 2015; 145: 334-346.

[36] Itoi $\mathrm{M}$, Tsukamoto $\mathrm{N}$, Yoshida $\mathrm{H}$, et al. Mesenchymal cells are required for functional development of thymic epithelial cells. Int Immunol. 2007; 19: 953-964.

[37] Jenkinson WE, Jenkinson EJ, Anderson G. Differential requirement for mesenchyme in the proliferation and maturation of thymic epithelial progenitors. J Exp Med. 2003; 198: 325-332.

[38] Jenkinson WE, Rossi SW, Parnell SM, et al. PDGFR $\alpha$-expressing mesenchyme regulates thymus growth and the availability of intrathymic niches. Blood 2007; 109: 954-960.

[39] Morrison-Graham K, Schatteman GC, Bork T, et al. A PDGF receptor mutation in the mouse (Patch) perturbs the development of a non-neuronal subset of neural crest-derived cells. Development 1992; 115: 133-142.

[40] Klug DB, Carter C, Gimenez-Conti IB, et al. Cutting edge: thymocyte-independent and thymocyte-dependent phases of epithelial patterning in the fetal thymus. J Immunol. 2002; 169: 2842-2845.

[41] Rossi SW, Chidgey AP, Parnell SM, et al. Redefining epithelial progenitor potential in the developing thymus. Eur J Immunol. 2007; 37: 2411-2418.

[42] Cordier AC, Haumont SM. Development of thymus, parathyroids, and ultimo-branchial bodies in NMRI and nude mice. Am J Anat. 1980; 157: 227-263.

[43] Cordier AC, Heremans JF. Nude mouse embryo: ectodermal nature of the primordial thymic defect. Scand J Immunol. 1975; 4: 193-196.

[44] Bleul CC, Corbeaux T, Reuter A, et al. Formation of a functional thymus initiated by a postnatal epithelial progenitor cell. Nature 2006; 441: 992-996.

[45] Varga I, Pospisilova V, Jablonska V, et al. Thymic Hassalls's bodies of children with congenital heart defects. Bratisl Lek Listy 2010; 111: 552-557.

[46] Bódi I, Kocsis K, Benyeda Z, et al. Dual secretion locations on type II cells in the avian lung suggest local as well as general roles of surfactant. J Morphol. 2016; 277: 1062-1071.

[47] Dooley J, Erickson M, Farr AG. An organized medullary epithelial structure in the normal thymus expresses molecules of respiratory epithelium and resembles the epithelial thymic rudiment of nude mice. J Immunol. 2005; 175: 4331-4337.

[48] Savino W, Mendes-da-Cruz DA, Silva JS, et al. Intrathymic T-cell migration: a combinatorial interplay of extracellular matrix and chemokines? Trends Immunol. 2002; 23: 305-313.

[49] Romano R, Palamaro L, Fusco A, et al. From murine to human nude/SCID: the thymus, T-cell development and the missing link. Clin Dev Immunol. 2012; 2012: 467101.

(Oláh Imre dr., Budapest, Túzoltó u. 58., 1094 e-mail: olah.imre@med.semmelweis-univ.hu) 